Original article

\title{
Krom Zenginleştirme Tesislerinde, Gürültü Şiddetinin Çalışanlara Etkilerinin Karşılaştırmalı Olarak İncelenmesi
}

\section{Comparative Investigation of the Effects of Noise Level on Workers in Chrome Processing Plants}

\author{
Mustafa Özgür Keskin \\ Department of Occupational Health and Safety, Karaisalı Vocational School, Çukurova University, Adana, Turkey
}

\begin{abstract}
Özet
Madencilikte, metalik cevherlerin zenginleştirilme işlemleri, farklı şekillerde gerçekleştirilebilmelerine rağmen, genelde prosesler; hazırlama işlemleri, boyut küçültme ve sınıflandırma gibi ön işlemleri kapsamaktadır. Bu işlemler, gürültü düzeyi oldukça yüksek seviyelere ulaşabilen büyük boyutlardaki makine ve yöntemlerle gerçekleştirilmektedir. Bu araştırmada, Adana ve Mersin bölgelerinde bulunan krom zenginleştirme tesisleri sallantılı masa ve değirmen katlarında, TS EN 61672-1 ve IEC 61672 standartlarına uygun Lutron SL-4010 dijital ölçüm cihazı ile gürültü şiddeti ölçümleri gerçekleştirilmiştir. Her iki tesiste, masa katları ile değirmen katları içerisindeki gürültü şiddeti değerlerinin 85-95 dB arasında değiştiği ve "Çalışanların Gürültü ile İlgili Risklerden Korunmalarına Dair Yönetmeliğe" göre bu değerlerin; maruziyet eylem değerleri ve maruziyet sınır değerleri üzerinde olduğu tespit edilmiştir. Bununla birlikte, belirlenen gürültü şiddeti değerleri karşılaştırmalı olarak incelenmiş, çalışanlar üzerindeki etkileri mevzuat doğrultusunda değerlendirilmiş ve bu etkilerinin önlenebilmesi için yapılması gerekenler belirlen meye çalışılmıştır.
\end{abstract}

Anahtar Kelimeler: Cevher Hazırlama, Sallantılı Masa, Değirmen, Gürültü Şiddeti.

\begin{abstract}
In mining, ore dressing can be carried out in different techniques, but generally processes; include pretreatments such as preparation, sizing and classification. These operations are carried out by large-scale machines and methods that can achieve very high levels of noise. In this study, the noise level values occured at various stages of production in chrome ore facilities in Adana and Mersin regions, noise level measurements were carried out with the Lutron SL-4010 digital measuring device in accordance with TS EN 61672-1 and IEC 61672 standards. According to the "Regulation on the Protection of Workers from Risks Related to Noise", in both facilities, the noise levels within the table and mill floors vary between 85-95 dB; upper exposure action values and exposure limit values were found to be above. In addition, the determined noise pressure values were comparatively studied, their effects on the workers were evaluated in accordance with the legislation, and efforts were made to identify these effects.
\end{abstract}

Keywords: Ore Dressing, Shaking Table, Mill, Noise Level.

Received: 16 April 2020 * Accepted: 01 June $2020 \quad * \quad$ DOI: https://doi.org/10.29329/ijiasr.2020.259.2

\footnotetext{
* Corresponding author:

Mustafa Özgür Keskin, Department of Occupational Health and Safety, Karaisalı Vocational School, Çukurova University, Adana, Turkey Email: okeskin@cu.edu.tr
} 


\section{GíRiş}

Maden ocaklarında üretilen cevher ya da hammaddeler, üretim ve sanayide kullanılabilecek kısımlarla birlikte, fazla miktarlarda kullanılmayan kısımlarını da içermektedir. Çeşitli yöntemlerle üretilen bu malzemelerden metalik olanlar cevher olarak adlandırılır. Endüstrinin kullanımı için bu cevherin yan taşlarından ve artıklarından ayrıştırılması gerekmektedir. Cevher hazırlama ve zenginleştirme alanında, artık ya da gang olarak adlandırılabilen bu kısmın çeşitli yöntemlerle ayrılması, endüstriyel üretimde maliyeti azaltmak, ürün kalitesi ile kapasite ve verimi artırmak için gerçekleştirilmektedir. Bu ayrıştırma işlemlerinin tamama yakını, sınıflandırma ve boyut küçültme gibi, malzemenin kolaylıkla ayrıştırılması için ön işlemlerle başlamaktadır. Boyut küçültme işlemlerinde; iri boyutlar için kırma ve küçük boyutlar için öğütme yapılmaktadır. Bu işlemlerin her aşamasında ise sınıflandırma için eleme ya da hidrosiklon gibi farklı teknikler kullanılabilmektedir. Zenginleştirme kısmında ise özellikle krom üretiminde kullanılan kromit cevherinde, sallantılı masa yöntemi gibi yöntemler tercih edilebilmektedir. Genel bir krom cevheri hazırlama ve zenginleştirme tesisinde ise, ocaktan getirilen cevherin boyutunun küçültmesi, sınıflandırılması ve konsantre eldesi için gravimetrik olarak zenginleştirilmesi işlemleri birbirini takip edecek şekilde dizayn edilir. Bu işlemlerin tamamının yapıldığı tesislere de zenginleştirme tesisleri adı verilmektedir. Farklı tasarımlarda yapılmasına rağmen, kırma işlemi kırıcılarda, öğütme işlemi değirmenlerde, sınıflandırma işlemi eleklerde ve zenginleştirme işlemi de sallantılı masalarda gerçekleştirilir. Her aşamada, enerji tahrikli mekanizmalar, dişli ve metalik aksamlar sebebiyle, yüksek ve zararlı düzeyde gürültü oluşabilmektedir. Bir arada çalışan makine ve ekipmandan kaynaklanan, tesislerde ortaya çıkan bu gürültü seviyeleri, çalışanların sağlık ve güvenlikleri açısından ciddi sorun ve kazalara yol açabilmektedir [14]. Özellikle, mevzuat doğrultusunda maruz kalınabilecek, müsaade edilebilir değerlere ulaşmış ya da üzerine çıkmış değerlerin tespit edilmesi, zorunlu yapılması gereken uygulamalardandır. Ölçümler, dozimetrik ya da istasyonlar vasıtasıyla sürekli gerçekleştirilerek, ortamda meydana gelen gürültü miktarının, maruziyet sınır değerleriyle karşılaştırması yapılarak, gerekli önlemler alınır.

İSGİP (Türkiye’de İşyerlerinde İş Sağlığg ve Güvenliği Koşullarının İyileştirilmesi Projesi) kapsamında, Meslek Hastalıkları ve İş ile İlgili Hastalıklar Tanı Rehberi 1. Bölümde, Maden ve Taşocaklarında Sağlık Tehlikeleri ve Riskleri başlığında, fiziksel tehlikelerden gürültünün, genellikle dar ve kapalı alanlarda yürütülen madencilik çalışmalarında, her türlü alet ve makineden, kesme, delme, yükleme ve taşıma gibi işlemlerden kaynaklanan gürültü maruziyeti ile çalışanlarda, yalnızca işitme kayıpları gibi meslek hastalıklarına değil, aynı zamanda; iletişimi engellemesi, sinirlilik ve yorgunluğu artırmasıyla, iş kazalarında artışa neden olabileceği belirtilmiştir. Ayrıca, duyarlı kişiler dışında, günde 8 saat sürekli $85 \mathrm{~dB}$ altında gürültüye maruz kalmanın genellikle işitme kaybına neden olmayacağı, 100 $\mathrm{dB}$ gürültüye sürekli maruziyetin ise ortalama olarak; 5 yılda $5 \mathrm{~dB}, 20$ yılda $14 \mathrm{~dB}, 40$ yılda $19 \mathrm{~dB}$ işitme 
kaybına neden olacağı belirtilmektedir. Fizyolojik olarak, yaşa bağlı gelişen işitme kayıplarıyla birlikte, bu etki daha fazla artabilir [13].

2018 yılı T.C. Sosyal Güvenlik Kurumu, İş Kazası ve Meslek Hastalı̆̆ı İstatistiklerine göre; listede olmayan hastalıklar sebebiyle meslek hastalığına yakalananlar ile sigortalılığı sona erdikten sonra teşhis koyulanlar oran dişı tutulduğunda, 2018 yılında; iç kulakta gürültünün etkileriyle, kulak ve mastoid çıkıntı hastalıkları sınıfına giren meslek hastalıkları, yaklaşık \%9 ile 3. sırada yer almaktadır [15].

Literatürde, madencilik ve ilgili alanlarda, çalışma ortamından kaynaklanan gürültünün etkilerinin incelendiği Çizelge-1'de özetlenen, kırma ve öğütme tesislerinde yapılan çalışmalar incelendiğinde, metalik cevherlerin işlendiği tesislerde, kırıcıların ortalama; 90-114 dB aras1, değirmenlerin ise ortalama; 97-119 dB arası gürültü şiddeti oluşturdukları ve diğer proses ve tesislerde ise, kırıcıların ortalama; 90-106 dB arası, değirmenlerin ortalama; 87,7-103 dB arası gürültü oluşturduğu görülmektedir. Tespit edilmiş ortalama değerlerin tamamı, "Çalışanların Gürültü ile İlgili Risklerden Korunmalarına Dair Yönetmeliğe" göre; $87 \mathrm{~dB}$, maruziyet sınır değerinin üzerindedir[1,2,3,4,5,6,7,9,10,11].

Tablo 1. Literatürde, farklı kaynaklardaki kırıcı ve değirmenlerin gürültü seviyeleri.

\begin{tabular}{|l|l|l|l|}
\hline \multirow{2}{*}{ İşletme Türü } & \multicolumn{2}{|l|}{ Ortalama Gürülttü Düzeyleri, dB } & \multirow{2}{*}{ Kaynak } \\
\cline { 2 - 4 } & Kırıcı & Değirmen & \\
\hline Metalik & $93-94$ & - & {$[6]$} \\
\hline “ & $90-91$ & $97-98$ & “ \\
\hline Agrega & 98,4 & - & {$[9]$} \\
\hline “ & 97,6 & - & “ \\
\hline Çimento & 93,2 & $87,7-91,7$ & {$[1]$} \\
\hline Agrega & 92 & - & {$[11]$} \\
\hline Çimento & 106 & $101-103$ & {$[3]$} \\
\hline Metalik & $113-114$ & 119 & {$[7]$} \\
\hline Genel Madencilik & $90-100$ & $90-100$ & {$[10]$} \\
\hline Genel Madencilik & 96 & - & {$[2]$} \\
\hline
\end{tabular}

\section{Ses ve Gürültüi}

İnsan, çevresinde olup bitenleri duyuları vasıtasıyla algılar. Havadaki seslerin titreşerek meydana getirdiği dalgalar, duyu organındaki almaçlar (reseptörler) aracılı̆̆ıyla sinirler üzerinden beyne iletilir. Kulak ve içyapısı oldukça hassas olduğu için alınan sesler ve oluşturduğu basınçla ilgili, bazı tanımlar yapmak gerekir. Ses, titreşim yapan herhangi bir kaynaktan ortaya çıkan hava basıncı dalgalanmalar ile oluşan ve insanda işitme duyusunu uyaran fiziksel bir olaydır. Gürültü ise dinlenmekte olan seslere karışan istenmeyen herhangi bir ses olarak tanımlanır. Sesbilimde periyodik olmayan frekanslardan 
oluşan ses birimlerinin oluşturduğu tayfı tanımlamaktadır [8]. Sıklıkla insanlar gürültüyü, işitme duyusuna zarar veren yüksek seslerle ilişkilendirir[4,5]. Çalışma ortamları düşünüldüğünde, istenmeyen ve rahatsız edici seslerin tamamı da gürültü olarak tanımlanabilir. Vibrasyon ise, genellikle katı ortamlarda yayılan ve dokunma duygusu ile hissedilen alçak frekanslı ve yüksek genlikli mekanik titreşimlerdir [8]. Gürültü ve titreşim, birbirinden bağımsız olgular olmadığından, her zaman birlikte değerlendirilir.

$\mathrm{dB}(\mathrm{A})$, insan kulağının en çok hassas olduğu orta ve yüksek frekansların özellikle vurgulandığı bir ses değerlendirmesi birimidir. Gürültü azaltılması veya kontrolünde çok kullanılan $\mathrm{dB}(\mathrm{A})$ birimi, ses yüksekliğinin subjektif değerlendirmesi ile de ilişkilidir. Frekans, ses dalgalarının birim zamandaki titreşim sayısı olarak tanımlanabilir ve birimi Hertz'dir [8].

Sesin iki temel karakteristiği frekans ve şiddettir. Sesin şiddeti doğrudan kulak zarına ulaşan mekanik basınçla ilişkilidir. Frekans saniyedeki titreşim sayısıdır ve sesin yüksek mi yoksa düşük mü olduğunu tanımlamaktadır. Belirli bir yoğunlukta düşük frekansların işitme kayıplarına yol açma olasılığı daha yüksektir. Ses tahmin edilmeyen ve kontrol edilemeyen nitelik kazandıkça, rahatsız edici özelliği büyük oranda artar. Gürültü ise havada bulunan partiküllerin ses dalgalarının etkisiyle sıkışıp genleşmesine bağlı olarak ortaya çıkan bir etkidir [8].

Tanımlanmış, duyulabilir frekansın en küçük ses basınç seviyesine işitme eşiği denir. İşitme eşiği, belirli koşullar altındaki sesin düzeyi olarak tanımlanır (ISO 226:2003). Sese duyarlılık; ses basınç düzeyi ile ses frekansı gibi iki faktöre bağlıdır. İnsan işitme sistemi, en fazla $4 \mathrm{kHz}$ civarındaki frekanslarda olan seslere duyarlıdır. İşitmesi iyi durumda olan genç insanlar için, bu frekans aralığ için işitme eşiği de, $3 \mathrm{~dB}$ 'dir [8].

\section{Gürültü ve Özellikleri}

\section{Gürültüi Türleri}

Gürültünün türü, onun sahip olduğu frekans bantlarına, ses düzeyinin zamanla değişimine ve ses alanlarının yapısına bağlıdır [8]. Spektrum ve zamana bağlı olarak, gürültünün sınıflandırılması Çizelge2'de verilmiştir. 
Tablo 2. Spektrum ve zamana bağlı gürültü sınıfları [8].

\begin{tabular}{|l|l|l|}
\hline Özellik & Gürültü Sınıfı & Açıklama-Örnek \\
\hline Frekans Bandına (Spektrum) Bağlı & Sürekli bant & $\begin{array}{l}\text { Bütün frekans aralıklarına sahip sürekli } \\
\text { spektrumlu-Makine }\end{array}$ \\
\cline { 2 - 3 } & Sürekli dar bant & Birkaç frekansın yoğun yer aldığı-Daire testere \\
\hline Zamana Bağlı & Karalı & $\begin{array}{l}\text { Önemli değişim göstermeyen-Çim biçme } \\
\text { makinesi }\end{array}$ \\
\cline { 2 - 3 } & Kararsız & $\begin{array}{l}\text { Önemli ölçüde değişiklik gösteren-İş makineleri } \\
\text { motor devri }\end{array}$ \\
\cline { 2 - 3 } & Dalgalı & $\begin{array}{l}\text { Sürekli ve önemli ölçüde değişiklik gösteren- } \\
\text { Otomatik pres }\end{array}$ \\
\cline { 2 - 3 } & Kesikli & $\begin{array}{l}\text { Yüksek değerlerde, 1 saniye ya da fazla sabit } \\
\text { devam eden-Trafik }\end{array}$ \\
\cline { 2 - 3 } & Vurma & $\begin{array}{l}\text { Saniyeden az süren bir ya da daha çok vuruş- } \\
\text { Çekiç }\end{array}$ \\
\hline
\end{tabular}

\section{Gürülttünün Sağlık Üzerindeki Etkisi}

Gürültünün en önemli etkisi, işitme duyusunda meydana getirdiği hasarlar ve işitme kayıplarıdır. İşitmedeki hasar ve kayıplar, işitme eşiği düzeyi ile belirlenebilir. İşitme eşiği yüksekliği, sesin belirli frekanslarda duyumunu azaltmaktadır. İşitme kaybının çeşitli türleri olmakla birlikte, en yaygın işitme kaybı, 2-6 kHz aralığındaki frekanslarda endüstriyel gürültüye bağlı 'yüksek frekansta işitme kaybı' olarak adlandırılan işitme kaybıdır[4,5].

Yaşamdaki gürültü türleri; sürekli geniş band gürültüsü ile sürekli dar band gürültüsünün bileşimi şeklindedir. Geniş band gürültüsü frekansı tüm frekans bandını kapsayacak biçimde yayılım gösterir. Dar band gürültüsünde ise daire testerenin ç1kardığı gürültüde olduğu gibi gürültü belirli frekanslarda yoğunlaşmaktadır. Bu gürültünün seviyesinde zamana bağlı önemli değişiklikler olabilir. Bu tip gürültü kararsız gürültü olarak adlandırılır ve dalgalı, kesikli ve darbeli olmak üzere üç sınıfa ayrılır [8].

Gürültünün çalışma ortamlarında, ortam ve çalışana etkileri aşağıdaki gibidir [8];

- Maskeleme yaparak, duyulması gerekli olan diğer sesleri engeller,

- Çalışan iletişimini engeller,

- Psikolojik baskılama yaparak, karar vermede ve tepkide gecikme ve sapmalara sebep olur,

- Birikimsel olarak değerlendirildiğinde, işitme duyusunda kümülatif hasar meydana getirir,

- Ani gürültüler davranışşsekillerini etkiler,

- Sesler arası nitelik ayrımı güçleşir, 
- Sürekli gürültülü ortamda çalışma sonucu, çalışanlarda, uyku ve beslenme bozuklukları yaşanabilir.

\section{Gürülltü Maruziyeti}

\section{- Maruziyet Eylem Değerleri ve Maruziyet Sınır Değerleri}

"Çalışanların Gürültü ile İlgili Risklerden Korunmalarına Dair Yönetmeliğe” göre; maruziyet eylem değerleri ve maruziyet sınır değerleri Çizelge-3’te verilmiştir [4,5].

Tablo 3. Çalışanların Gürültü ile İlgili Risklerden Korunmalarına Dair Yönetmeliği, 5. maddeye göre; maruziyet eylem ve sinır değerleri.

\begin{tabular}{|l|l|}
\hline Maruziyet Değeri Tanımı & Zaman Ağırlıklı Ortalama Değer \\
\hline En düşük maruziyet eylem değerleri & $\left(\mathrm{LEX}_{\mathrm{EX}, 8 \text { saat }}\right) 80 \mathrm{~dB}(\mathrm{~A})$ veya $\left(\mathrm{P}_{\text {tepe }}\right)=$ \\
& $112 \mathrm{~Pa}[135 \mathrm{~dB}(\mathrm{C})$ re. $20 \mu \mathrm{Pa}](20 \mu$ Pa referans \\
& alındığında $135 \mathrm{~dB}(\mathrm{C})$ olarak hesaplanan değer $)$ \\
\hline En yüksek maruziyet eylem değerleri & $\left(\mathrm{LEX}_{\mathrm{EX}, 8 \text { saat }}\right)=85 \mathrm{~dB}(\mathrm{~A})$ veya $\left(\mathrm{P}_{\text {tepe }}\right)=$ \\
& $140 \mathrm{~Pa}[137 \mathrm{~dB}(\mathrm{C})$ re. $20 \mu \mathrm{Pa}]$ \\
\hline Maruziyet sınır değerleri & $\left(\mathrm{LEX}_{\mathrm{EX}, 8 \text { saat }}\right)=87 \mathrm{~dB}(\mathrm{~A})$ veya $\left(\mathrm{P}_{\text {tepe }}\right)=$ \\
& $200 \mathrm{~Pa}[140 \mathrm{~dB}(\mathrm{C})$ re. $20 \mu \mathrm{Pa}]$ \\
\hline
\end{tabular}

Günlük gürültü maruziyetinin günden güne belirgin şekilde farklılık gösterdiğinin kesin olarak tespit edildiği işlerde, haftalık gürültü maruziyet düzeyi kullanılabilir ve bu işlerde; yeterli ölçümle tespit edilen haftalık gürültü maruziyet düzeyi, $87 \mathrm{~dB}(\mathrm{~A})$ maruziyet sınır değerini aşamaz[14].

Maruziyet sınır değerleri, işitme için tehlike eşiği olarak kabul edilen $80 \mathrm{~dB}$ düzeyi ve üzerindedir. Bu değerlerden başlayarak $120 \mathrm{~dB}$ seviyesine kadar olan düzeylerde, zamanla işitmede kayıplar ortaya çıkmakta, birikimsel olarak değerlendirildiğinde ise işitme kaybı sürekli hale gelmektedir. $140 \mathrm{~dB}$ ve üzerindeki gürültü seviyeleri ise, anlık basınç düşünüldüğünde, çok kısa maruziyet hallerinde bile işitme kayıplarına yol açabilir [14].

\section{- Gürültü̈ Maruziyetinin Belirlenmesi}

Yönetmeliğe göre; gürültü ölçümünde kullanılacak yöntem ve cihazlar; mevcut şartlara uygun, maruziyet sınır ve maruziyet eylem değerlerini tespit edebilen, çalışanın maruziyetini gösterecek şekilde seçilir [14].

Eşdeğer sürekli ses basınç değeri maruziyeti belirlenirken, vardiyada, kişi maruziyeti ve gürültü kaynağından çalışma ortamına yayılan gürültü seviyesinin tespitinde, dozimetrik çalışan ölçümü gerçekleştirilmesi ile çevresel ölçümler, hem çalışanın algıladığ belirlenebilmesi için gereklidir. Gürültü şiddeti seviyesi belirlemede, genellikle, 0-130 ya da 0-140 dB aralığında ölçüm yapabilen, taşınabilir gürültü şiddeti ölçüm cihazları kullanılır. 


\section{- Maruziyetin Önlenmesi ve Azaltılması}

"Çalışanların Gürültü ile İlgili Risklerden Korunmalarına Dair Yönetmelik" kapsamında, çalışanların gürültü maruziyetlerinin önlenebilmesi için sırasıyla; kaynağında önleme, bu mümkün değilse gürültülü ortamdan ayırma, yayılma ve iletimin engellenmesi ya da azaltılması ile kişisel korunma yöntemleri tercih edilir. Teknik olarak, çalışma alanlarında gürültünün etkilerini azaltmak için mümkünse daha az gürültülü yöntem tercih edilebilir. Farklı yöntem seçimi mümkün olmadığında, gürültünün kaynağında azaltılması için izolasyon önlemleri alınabilir. Çalışan, gürültülü yöntem ve makinelerin ayrılması da bir seçenektir. Her şekilde, çalışanların gürültünün olumsuz etkilerinden korunabilmesi için çalışma şartlarına uygun kişisel koruyucu kullanımı, zorunludur. İş planında, gürültüye maruz kalınan sürenin azaltılması ve molaların, makul düzeyde düşük gürülttünün olduğu ya da sessiz ortamlarda değerlendirilmesinin sağlanması da gereklidir [4].

\section{- Kişisel Korunma}

Çalışma ortamlarında, anlık gürültülerden korunma amacıyla, tek kullanımlık ya da her kullanımda temizlenebilen türde kulak tıkaçları kullanılabilir. Sürekli gürültü oluşan ortamlarda ise standartlara uygun (TS-EN-352), baş koruyucularla kullanılabilen barete monteli ya da manşonlu kulaklıkların kullanılması gereklidir. Kulak koruyucu olarak kullanılan kulaklıklar, çalışma ortamlarındaki rahatsız edici gürültü şiddetini filtreleyerek, normal konuşma şiddeti olan 55-65 dB seslerin duyumunu engellemez. Bu sayede, konuşmaları ve uyarıcı sesleri duymaya devam edilebilir [14].

\section{- Çalışanların Bilgilendirilmesi ve Ĕ̆itimi}

Çalışanlara verilmesi gerekli iş sağlığı ve güvenliği eğitimlerinde; gürültünün ortaya çıkarabileceği riskler, önlenmesi için yapılması gerekenler ile yasal hak ve sorumluklar kapsamında bilgilendirme yapılır. Bununla birlikte, kişisel ve toplu korunma teknikleri ile etkin kişisel koruyucu kullanımı hakkında, hem bu eğitim içeriğinde hem de kişisel koruyucu donanım eğitiminde detaylı bilgiler verilmelidir [4].

\section{MATERYAL VE YÖNTEM}

Kulak 0-140 dB arası sesleri algılamaktadır. 120 dB değerinde kulakta rahatsızlık olur, 125-130 $\mathrm{dB}$ arası sesler kulakta belirgin ağrı nedenidir. $140 \mathrm{~dB}$ değerinde ise ağrı, kulak zarı yırtılması gibi etkiler ortaya çıkabilmektedir. Bu kulakta kalıcı zararların ortaya çıkması anlamına gelmektedir [14]. Çalışma ortamlarında, makine ve yöntem kaynaklı ortaya çıkan gürültü seviyeleri, dönen ve birbirine çarpan parçalardan, güç ve enerji devrelerinden kaynaklanabilir ve düzeyleri genellikle $80 \mathrm{~dB}$ değerinin üzerindedir. $80 \mathrm{~dB}$ üzeri her değer, mevzuatta müsaade edilen en düşük maruziyet eylem değerinin üzerinde kabul edilir ve çalışanların kulak koruyucuları hazır bulundurmaları zorunluluğunu doğurur. 


\section{Gürültü Ölçüm Yöntemi}

Gürültünün ortama yayılımı ve çalışan üzerindeki etkilerinin tespit edilebilmesi için farklı yöntemler uygulanabilmesine rağmen, hemen tamamında gürültünün duyu organına etkisi için şiddetini $\mathrm{dB}$ cinsinden ölçebilen cihazlar tercih edilmektedir. Çalışmada, gürültü şiddeti ölçümünde; 31,5-8000 Hz frekans ve 30-130 dB ölçüm aralığına sahip Lutron SL-4010 (IEC 61672;TS EN 61672-1) türü, dijital ölçüm cihazı kullanılmıştır (Şekil-1). Ölçümler, krom zenginleştirme tesislerinde; vardiya süresince, A-zaman ağırlıklı gürültü maruziyeti türünde $(\mathrm{dB}(\mathrm{A}))$, değirmen katı ile tesislerde her masa katında, çalışma alanlarında ve çevresel olarak gerçekleştirilmiştir (Şekil-3,4,5 ve 6). Ölçümler, TS EN ISO 9612 standardına göre iş tabanlı olarak; vardiya boyunca, çalışan sayısı üzeriden belirlenen sürelerde, asgari beş örnek üzerinden, çalışanların bulunduğu noktalarda dozimetrik olarak gerçekleştirilmiş ve ortalama değerler üzerinden 10 değer tespit edilmiştir. Çalışanların tesis içerisinde sürekli bulunduğu ve hareket ettiği güzergâhlarda, farklı vardiyalarda ve vardiya sürelerince gerçekleştirilmiştir. TS EN ISO 9612 standardında; çalışanın, iş istasyonunda olması gereken durumlarda, mikrofon en çok maruz kalan kulağın tarafında ve dış kulak kanal girişinden $0,1 \mathrm{~m}$ ve 0,4 $\mathrm{m}$ arasında bir mesafede tutulması veya yerleştirilmesi ya da çalş̧anın faaliyeti veya iş istasyonunun tasarımı, mesafenin 0,4 m'de tutulmasına izin vermiyorsa, çalışanın elbisesine takılan bir cihazın kullanılması tavsiye edilmektedir. Ayrıca, ayakta çalışanlar için çalışanın ayakta durduğu zeminden 1,55 $\mathrm{m} \pm$ 0,075 m yukarıda gerçekleştirilmesi gerekliliği belirtilmektedir. Bu doğrultuda, çalışan maruziyet ölçümü için ölçüm cihazı, çalışanın dış kulak girişine en fazla $30 \mathrm{~cm}$ mesafede ve çalışana başka bir güvenlik riski oluşturmayacak şekilde yaka kısmına yerleştirilmiş, vardiya boyunca tespit edilen gürültü seviyeleri kaydedilmiştir. Çevresel ölçümlerde ise kişisel koruyucu kulaklık takılarak, değirmen ve masalar etrafında, yapının güvenlik açısından imkân verdiği tüm yönlerde ve en fazla 1-5 m arasındaki mesafelerde, vardiya boyunca gürültü seviyeleri ölçülmüş ve kaydedilmiştir. Ölçülen değerlerin, farklı vardiyalardaki ortalamaları bulunarak, yönetmelikte müsaade edilen değerlerle karşılaştırması yapılarak değerlendirilmiştir $[4,5,16,17]$. 


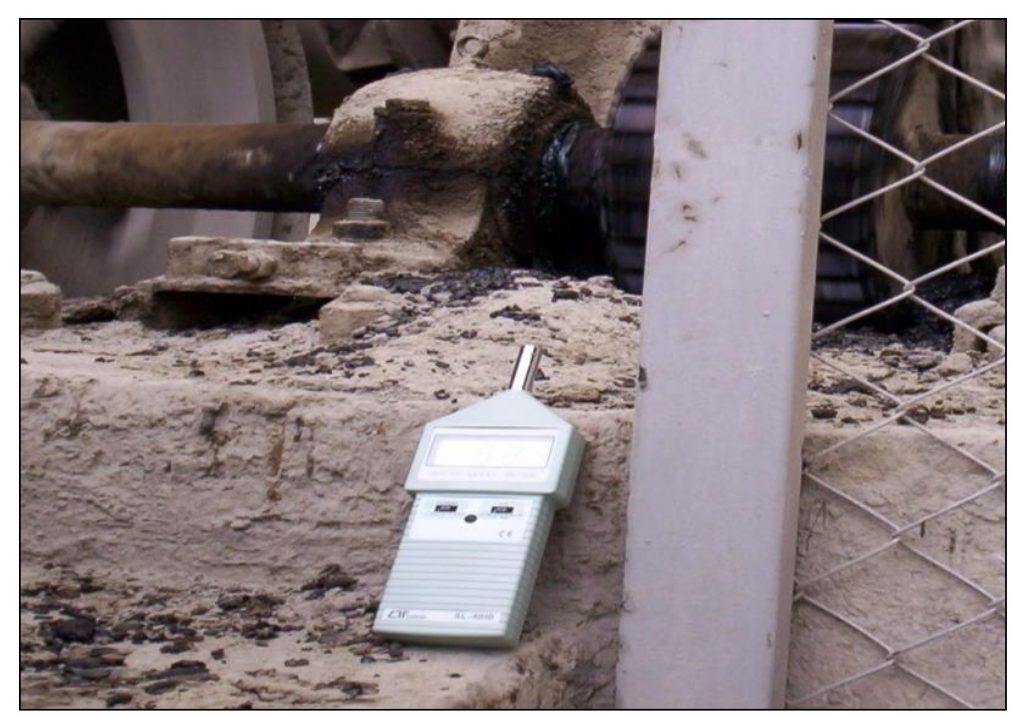

Şekil 1. Gürültü seviyesi ölçüm cihazı.

Ölçümlemelerde, çalışan ölçümleri gerçekleştirilirken, işitme duyusu etkilenme noktaları olan kulaklara yakın bölgelerden değerler alınmıştır. Çevresel değerler için güvenli mesafelere dikkat edilerek, gürültü kaynaklarına en yakın noktalarda ölçümler gerçekleştirilmiştir [16,17].

\section{Çalış̧ma Alanları}

\section{- Adana-Aladă̆-Kıcak Krom Zenginleştirme Tesisi}

Adana ili Aladă̆ ilçesi Kıcak köyü mevkiinde bulunan krom zenginleştirme tesisinin (Şekil-2) hammadde ihtiyacı, 5 adet krom ocağı tarafından karşılanmakta ve tesiste, biri 60'lık diğeri 90'lık olmak üzere iki adet kırıcı, 2 adet değirmen ve 2'si ara ürün için olmak üzere 22 adet sallantılı masa bulunmaktadır. Tesis, 24.000 ton/y1l konsantre üretim kapasitesine sahiptir. Ocaklardan gelen cevherin kırıcıdan geçen kısmı tesis içerisinde, değirmen katında boyutlandırılmakta ve 2 farklı masa katında zenginleştirilmektedir (Şekil-3 ve 4). Çalışanlar, çalışma alanının tüm noktalarında bulunabilmekte fakat, vardiya süresince en yoğun süreleri, değirmen katı ve sallantılı masaların bulunduğu masa katlarında geçirmektedirler. Bu alanların gürültü seviyeleri, yakın mesafelerde, normal ve yüksek sesle konuşmaların işitilemeyeceği seviyelere çıkmaktadır. Bu kısımlar, tesis içerisinde kaldığından, çalışanlar doğrudan etkilenmektedirler. 


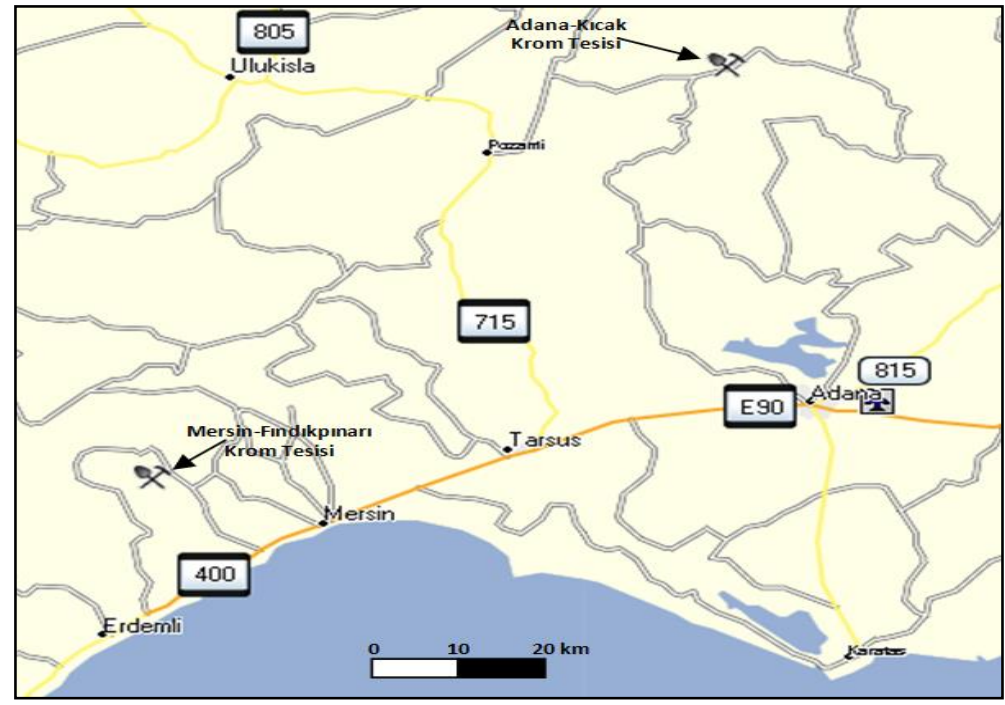

Şekil 2. Çalışma alanları yerbulduru haritası.

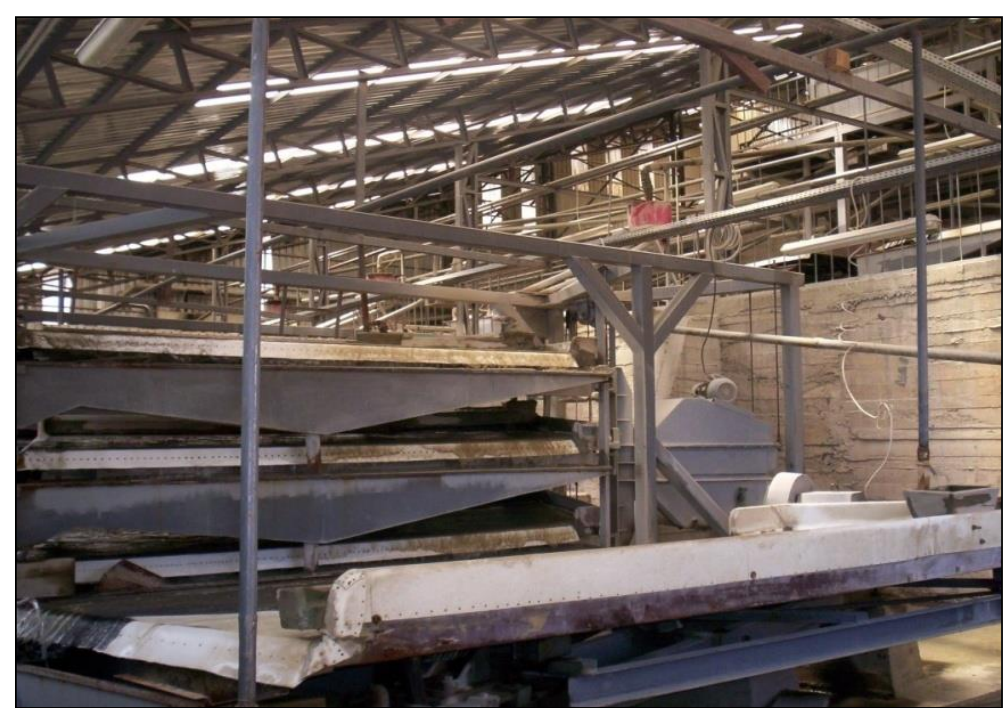

Şekil 3. Adana-Aladağ-Kıcak krom zenginleştirme tesisi sallantılı masa katı genel görünümü.

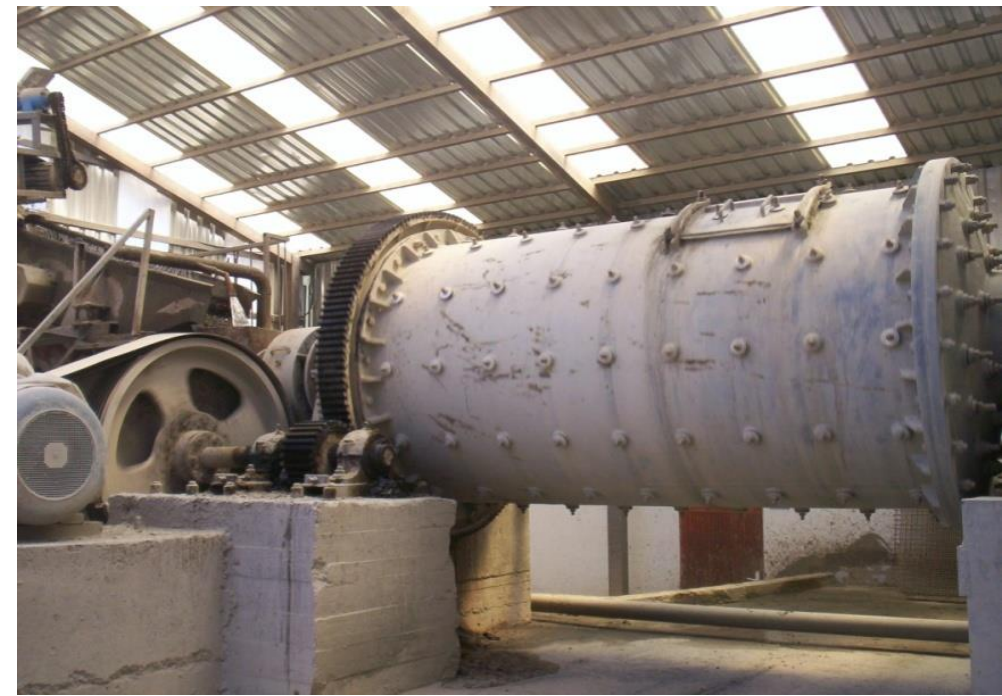

Şekil 4. Adana-Aladağ-Kıcak krom zenginleştirme tesisi değirmen katı genel görünümü. 


\section{- Mersin-Fındıkpınarı Krom Zenginleştirme Tesisi}

Mersin ili Mezitli ilçesi Fındıkpınarı beldesi mevkinde bulunan krom zenginleştirme tesisinin (Şekil 2) hammadde ihtiyacı, 2 adet krom ocağı tarafından karşılanmakta ve tesiste, 1 adet 60'lık kırıcı, 3 adet değirmen ve 28 adet sallantılı masa bulunmaktadır. Tesis 3 vardiya çalışmayla, 1.300 ton/ay konsantre üretim kapasitesine sahiptir. Tesisin ham maddesi olan krom cevheri (tüvenan), açık işletme çalışılan ocaklarda \%6-\%8 derecesinde bulunmakta, yeraltı (galeri) çalışması yapılan ocaklarda ise \%40 tenörlü parça krom olarak bulunmaktadır. Ocaklardan gelen cevherin kırıcıdan geçen kısmı tesis içerisinde, değirmen ve 2 farklı masa katında zenginleştirilmektedir (Şekil-5 ve 6). Çalışanlar, çalışma alanının tüm noktalarında bulunabilmekte fakat, vardiya süresince en yoğun süreleri, değirmen katı ve sallantılı masaların bulunduğu masa katlarında geçirmektedirler. Bu alanların gürültü seviyeleri, yakın mesafelerde, normal ve yüksek sesle konuşmaların işitilemeyeceği seviyelere çıkmaktadır. Bu kısımlar, tesis içerisinde kaldığından, çalışanlar doğrudan etkilenmektedirler.

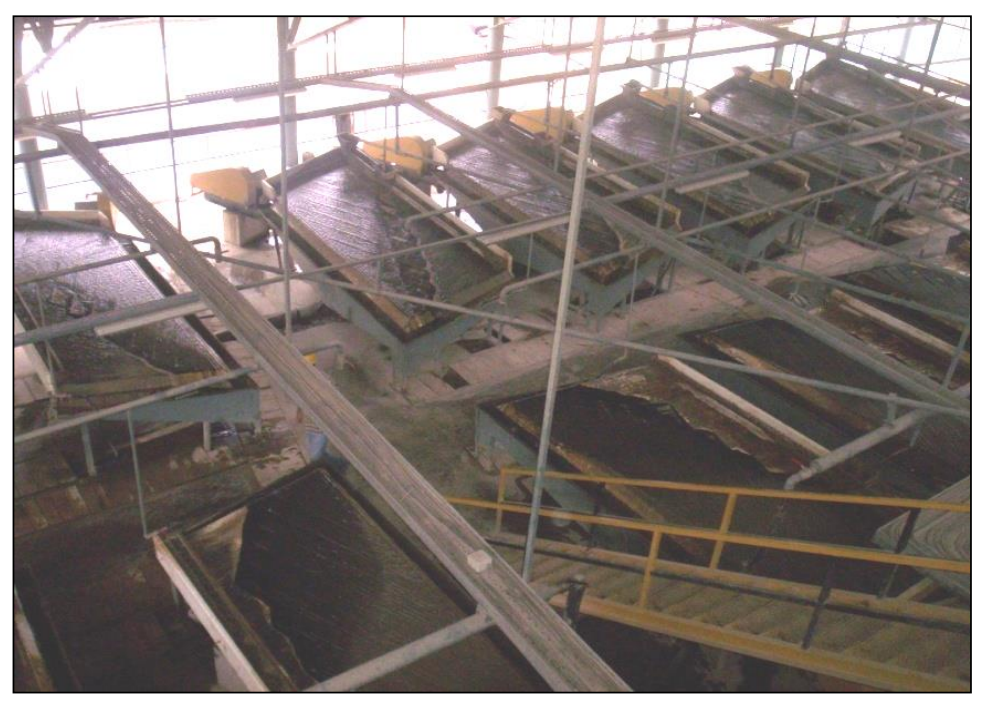

Şekil 5. Mersin-Fındıkpınarı krom zenginleştirme tesisi sallantılı masa katı genel görünümü.

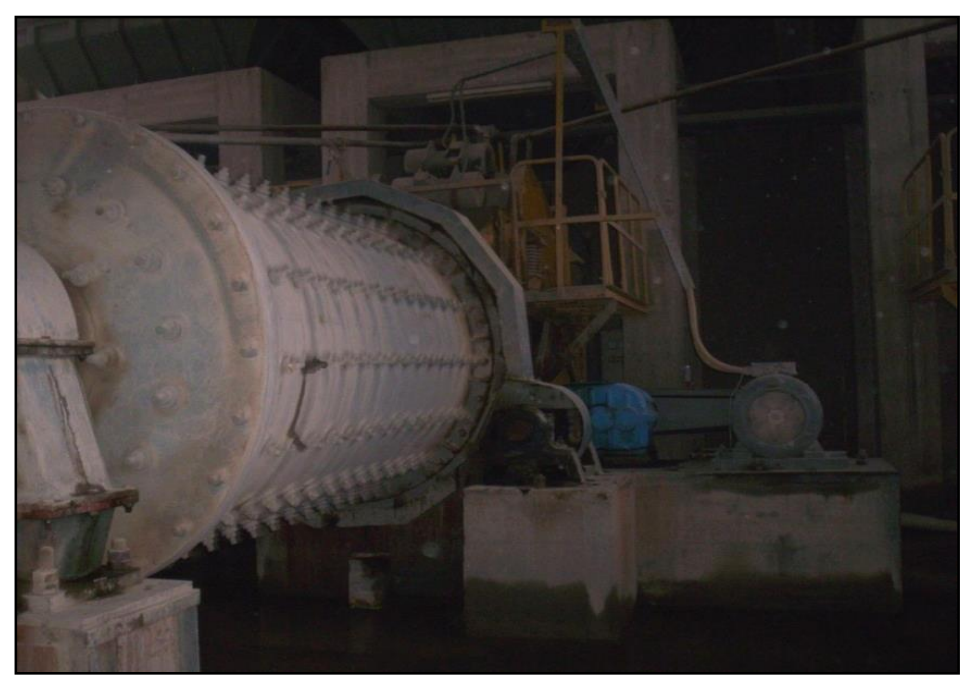

Şekil 6. Mersin-Fındıkpınarı krom zenginleştirme tesisi değirmen katı genel görünümü. 


\section{BULGULAR}

Türkiye'de krom yatakları belirgin bir dağılım düzeni göstermeksizin ultrabazik kayaçlar içinde ülke geneline yayılmış durumdadır. Türkiye'de 800 kadar tek veya grup halinde krom yatağı ve krom cevheri zuhuru bilinmektedir. Coğrafî yönden krom yataklarının dağılımını 6 bölgede toplamak mümkündür. Bunlar; Guleman (Elazı̆̆g), Fethiye-Köyceğiz-Denizli, Bursa-Kütahya-Eskişehir, MersinKarsantı-Pınarbaşı, Erzincan-Kopdağ ve İskenderun-Kahramanmaraş yöreleridir. Bu altı bölgenin dışında da dağınık bazı krom yataklarının bulunduğu bilinmektedir.

Krom cevheri, ocak çıkışında; elle seçme, elekten geçirme gibi yöntemlerle gang minerallerinin cevherin bünyesinden ayıklanması sonucu zenginleştirilebilmektedir. Daha ileri aşamada; jigler, spiraller, sallantılı masa gibi yöntemlerle, düşük tenörlü cevherin bünyesindeki gang temizlenerek kromit mineralinin zenginleşmesi ya da konsantre eldesi sağlanır. Konsantre krom cevheri üretiminde en yaygın uygulama, mineraller arasındaki yoğunluk farkı esasına dayalı sallantılı masa yöntemidir [4].

$\mathrm{Bu}$ çalışmada; Adana ve Mersin bölgelerindeki, gravimetrik yöntemle kromit zenginleştiren iki farklı tesisin, üretimin çeşitli aşamalarından kaynaklanan gürültü seviyeleri tespit edilmiştir.

\section{Cevher Hazırlama ve Zenginleştirme Tesislerinde Gürültü Ölçümleri}

Krom zenginleştirme tesislerinde, kromit ocaklarından gelen tüvenan cevher, 60 ya da 90 'llk çeneli kırıcılarla boyut küçültme işlemlerine tabi tutulduktan sonra, tane serbestleştirme işlemi için değirmenlerde öğütülmekte, ögütmeden çıkan; cevher, ara ürün ve gangdan oluşan malzeme, sallantılı masalara beslenerek zenginleştirme işlemi gerçekleştirilmektedir. Tesislerde çalışanlar, iç ortamda, kırma-öğütme devrelerinden ve sınıflandırma-zenginleştirme makinelerinden kaynaklı çevresel gürültüye maruz kalmaktadır.

Adana-Aladağ-Kıcak bölgesi krom zenginleştirme tesisi çalışma alanlarında; değirmen katında, kat içerisinde ölçülen vardiyadaki ortalama gürültü şiddeti $85,29 \mathrm{~dB}$ ve çevresel ölçülen gürültü şiddeti ise $81,74 \mathrm{~dB}$ değerlerinde, tesis sallantılı masa 1 . kat içerisinde ölçülen vardiyadaki ortalama gürültü şiddeti $87,80 \mathrm{~dB}$, sallantılı masa 2. kat içerisinde ölçülen ortalama gürültü şiddeti $86,45 \mathrm{~dB}$ ve çalışma esnasında katların çevresel gürültü şiddeti 71,2 dB değerlerindedir. Mersin-Mezitli-Fındıkpınarı bölgesi krom zenginleştirme tesisi çalışma alanlarında; değirmen katında, kat içerisinde ölçülen vardiyadaki ortalama gürültü şiddeti $91,65 \mathrm{~dB}$ ve çevresel ölçülen gürültü şiddeti ise $84,16 \mathrm{~dB}$ değerlerinde, tesis sallantılı masa 1. kat içerisinde ölçülen vardiyadaki ortalama gürültü şiddeti 87,83 dB, sallant1lı masa 2 . kat içerisinde ölçülen ortalama gürültü şiddeti 94,84 dB ve çalışma esnasında katların çevresel gürültü şiddeti 74,41 dB değerlerindedir. Her iki tesisin ölçüm sonuçları Çizelge-4 ve 5'te verilmiştir. 
Tablo 4. Adana-Aladağ-Kıcak krom zenginleştirme tesisi gürültü seviyesi ölçüm sonuçları.

\begin{tabular}{|l|c|c|c|c|c|}
\hline \multirow{2}{*}{$\begin{array}{l}\text { Vardiya } \\
\text { Ölçüm No }\end{array}$} & \multicolumn{5}{|c|}{ Gürültü Şiddeti Ölçüm Sonuçları (dB) } \\
\cline { 2 - 6 } & \multicolumn{3}{|c|}{ Krom Hazırlama Tesisi } & \multicolumn{2}{c|}{ Değirmen Katı } \\
\cline { 2 - 6 } & Çevresel & $\mathbf{1 .}$ Kat & $\mathbf{2 . ~ K a t}$ & İç & Dış \\
\hline 1 & 71,9 & 87,0 & 86,1 & 84,6 & 81,7 \\
\hline 2 & 72,5 & 87,1 & 85,9 & 84,4 & 82,8 \\
\hline 3 & 70,4 & 86,7 & 86,7 & 84,2 & 82,4 \\
\hline 4 & 73,3 & 88,0 & 86,8 & 86,1 & 82,6 \\
\hline 5 & 71,8 & 89,2 & 87,4 & 85,3 & 82,1 \\
\hline 6 & 74,0 & 88,3 & 86,1 & 84,7 & 81,7 \\
\hline 7 & 70,8 & 87,8 & 85,8 & 85,6 & 79,8 \\
\hline 8 & 70,8 & 87,5 & 86,8 & 85,1 & 80,7 \\
\hline 9 & 72,3 & 89,2 & 86,7 & 86,5 & 81,5 \\
\hline 10 & 71,4 & 87,2 & 86,2 & 86,4 & 82,1 \\
\hline$\sigma$ (Standart Sapma) & 1,1 & 0,9 & 0,5 & 0,8 & 0,9 \\
\hline Ortalama (dB) & $\mathbf{7 1 , 9 2}$ & $\mathbf{8 7 , 8 0}$ & $\mathbf{8 6 , 4 5}$ & $\mathbf{8 5 , 2 9}$ & $\mathbf{8 1 , 7 4}$ \\
\hline
\end{tabular}

Tablo 5. Mersin-Mezitli-Fındıkpınarı krom zenginleştirme tesisi gürültü seviyesi ölçüm sonuçları.

\begin{tabular}{|l|c|c|c|c|c|}
\hline \multirow{2}{*}{$\begin{array}{l}\text { Vardiya } \\
\text { Ölçüm No }\end{array}$} & \multicolumn{5}{|c|}{ Gürülttï Şiddeti Ölçüm Sonuçları (dB) } \\
\cline { 2 - 6 } & \multicolumn{3}{|c|}{ Krom Hazırlama Tesisi } & \multicolumn{2}{c|}{ Değirmen Katı } \\
\cline { 2 - 6 } & Çevresel & $\mathbf{1 .}$ Kat & $\mathbf{2 .}$ Kat & İç & Dış \\
\hline 1 & 73,4 & 88,4 & 94,1 & 90,7 & 84,4 \\
\hline 2 & 73,9 & 87,7 & 92,8 & 88,6 & 83,1 \\
\hline 3 & 74,2 & 88,2 & 94,3 & 89,1 & 82,2 \\
\hline 4 & 78,6 & 88,9 & 92,4 & 90,3 & 83,6 \\
\hline 5 & 72,5 & 87,9 & 95,0 & 92,4 & 84,3 \\
\hline 6 & 73,3 & 86,8 & 96,6 & 91,8 & 84,5 \\
\hline 7 & 72,9 & 86,2 & 95,6 & 94,1 & 84,8 \\
\hline 8 & 74,6 & 87,4 & 96,3 & 95,0 & 84,9 \\
\hline 9 & 75,6 & 88,7 & 95,5 & 91,0 & 85,0 \\
\hline 10 & 75,1 & 88,1 & 95,8 & 93,5 & 84,8 \\
\hline $\boldsymbol{\sigma}$ (Standart Sapma) & $\mathbf{1 , 8}$ & $\mathbf{0 , 8}$ & $\mathbf{1 , 4}$ & $\mathbf{2 , 1}$ & $\mathbf{0 , 9}$ \\
\hline Ortalama (dB) & $\mathbf{7 4 , 4 1}$ & $\mathbf{8 7 , 8 3}$ & $\mathbf{9 4 , 8 4}$ & $\mathbf{9 1 , 6 5}$ & $\mathbf{8 4 , 1 6}$ \\
\hline
\end{tabular}




\section{SONUÇLAR VE TARTIŞMA}

Adana-Aladağ-Kıcak ve Mersin-Mezitli-Fındıkpınarı krom hazırlama ve zenginleştirme tesislerinde, değirmen ve masa katlarında gerçekleştirilen gürültü seviyesi ölçüm sonuçlarının “Çalışanların Gürültü ile İlgili Risklerden Korunmalarına Dair Yönetmeliğin” maruziyet eylem ve maruziyet sınır değerlerinin üzerinde olduğu tespit edilmiştir. . Kıcak tesisinde değirmen katında, kat içerisinde ölçülen vardiyadaki ortalama gürültü şiddeti $85,29 \mathrm{~dB}$ ve çevresel ölçülen gürültü şiddeti ise $81,74 \mathrm{~dB}$ değerlerinde, tesis sallantılı masa 1 . kat içerisinde ölçülen vardiyadaki ortalama gürültü şiddeti $87,80 \mathrm{~dB}$, sallantılı masa 2. kat içerisinde ölçülen ortalama gürültü şiddeti $86,45 \mathrm{~dB}$ ve çalışma esnasında katların çevresel gürültü şiddeti $71,20 \mathrm{~dB}$ değerlerinde belirlenmiştir. Fındıkpınarı tesisi değirmen katında, kat içerisinde ölçülen vardiyadaki ortalama gürültü şiddeti $91,65 \mathrm{~dB}$ ve çevresel ölçülen gürültü şiddeti ise $84,16 \mathrm{~dB}$ değerlerinde, tesis sallantılı masa 1 . kat içerisinde ölçülen vardiyadaki ortalama gürültü şiddeti $87,83 \mathrm{~dB}$, sallantılı masa 2. kat içerisinde ölçülen ortalama gürültü şiddeti 94,84 dB ve çalışma esnasında katların çevresel gürültü şiddeti 74,41 dB değerlerinde belirlenmiştir.

Her iki tesiste ölçülen ortalama değerler, madencilik ve ilgili alanlardaki kırma ve öğütme tesislerinde yapılan çalışmalar incelendiğinde, kırıcı katlarındaki ortalama değerlerin, literatürdeki 90$114 \mathrm{~dB}$ arasındaki değer aralıklarında, değirmen katlarındaki ortalama değerlerin ise 97-119 dB arasındaki gürültü şiddeti değerlerinin altında olduğu belirlenmiştir. Bununla birlikte, masa katları çevresel ölçüm değerleri dışında kalan değerler, yönetmelikte belirtilen $80 \mathrm{~dB}$, en düşük maruziyet eylem değeri, $85 \mathrm{~dB}$ en yüksek maruziyet eylem değeri ve bazı değerlerle maruziyet sınır değerlerinin üzerinde olduğundan, işitme kaybının önlenebilmesi için çalışma alanlarında, gerek değirmen ve gerekse masa katlarında, gürültüyü kaynağında azaltabilmek için ses izolasyonu sağlayabilecek, makine muhafazalarının yapılması ve çalışma süresince, çalışanların kişisel koruyucu kulaklık kullanmasının sağlanması gerekmektedir. Ocaklarda gerçekleştirilen ölçüm sonuçlarının, mevzuatta belirtilen en düşük maruziyet eylem değerleri (E.D.M.E.D.), en yüksek maruziyet eylem değerleri (E.Y.M.E.D.) ve maruziyet sınır değerleri (M.S.D.) ile ilişkileri Şekil-7 ve 8'deki grafiklerde verilmiştir.

Benzer yöntemler ve makinelerin kullanıldığı, benzer işlemlerin yapıldığı her iki tesiste de; tesisin çevresel ortalama gürültü düzeyleri, en düşük maruziyet eylem değeri altında kalmasına rağmen tesis içerisindeki ölçüm sonuçları farklılık arz etmektedir. Kıcak tesisinde; değirmen katında ölçülen değerlerlerle masa 2. katında ölçülen değerler, en düşük ve en yüksek maruziyet eylem değerleri arasında, yalnızca masa 1. katında maruziyet sınır değerinin kısmen üzerinde belirlenmiştir. Fındıkpınarı tesisinde ise; yalnızca değirmen katı dış ölçüm sonuçlarının, en düşük ve en yüksek maruziyet eylem değerleri arasında, değirmen iç ve her iki masa katındaki ölçüm sonuçlarının maruziyet sınır değerlerinin üzerine çıktığı tespit edilmiştir. Bu sonuçlara göre; Mersin-Fındıkpınarı tesisinde, tesis içerisinde oluşan gürültü düzeyleri, Adana-Kıcak tesisine göre oldukça yüksektir. 


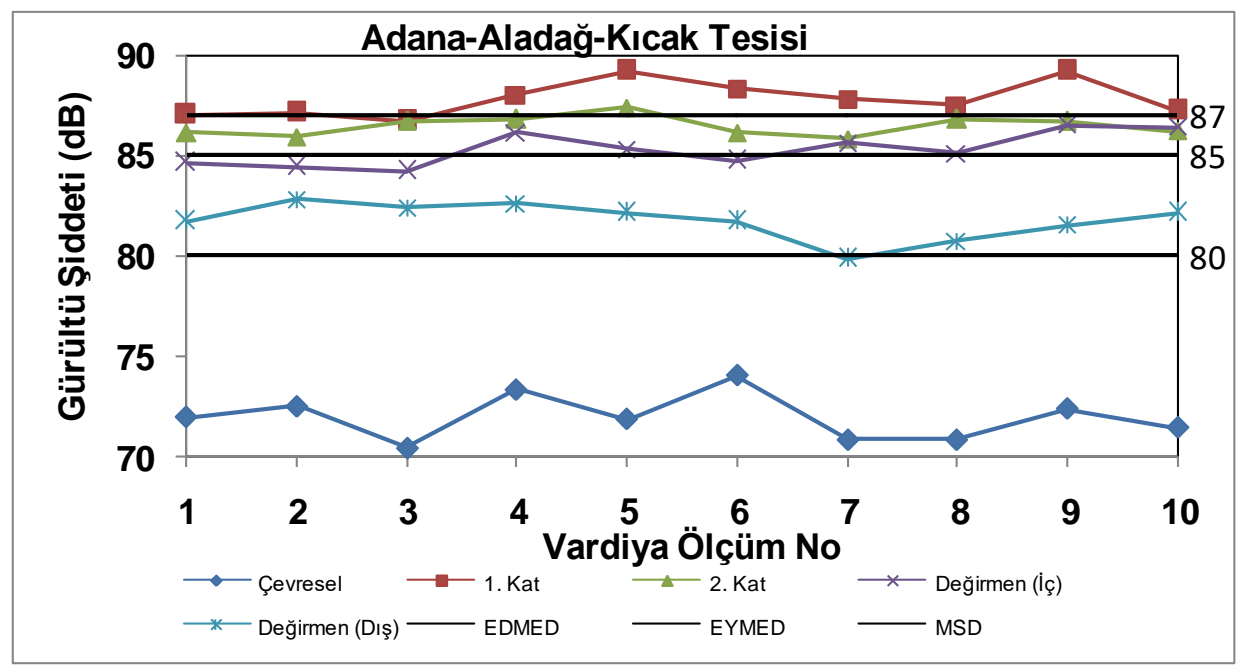

Şekil 7. Adana-Alada ğ-Kıcak krom zenginleştirme tesisinde gerçekleştirilen gürültü seviyesi ölçüm sonuçlarının yönetmelik en düşük ve en yüksek maruziyet eylem değerleri ile maruziyet sınır değerleri karşılaştırma grafiğgi.

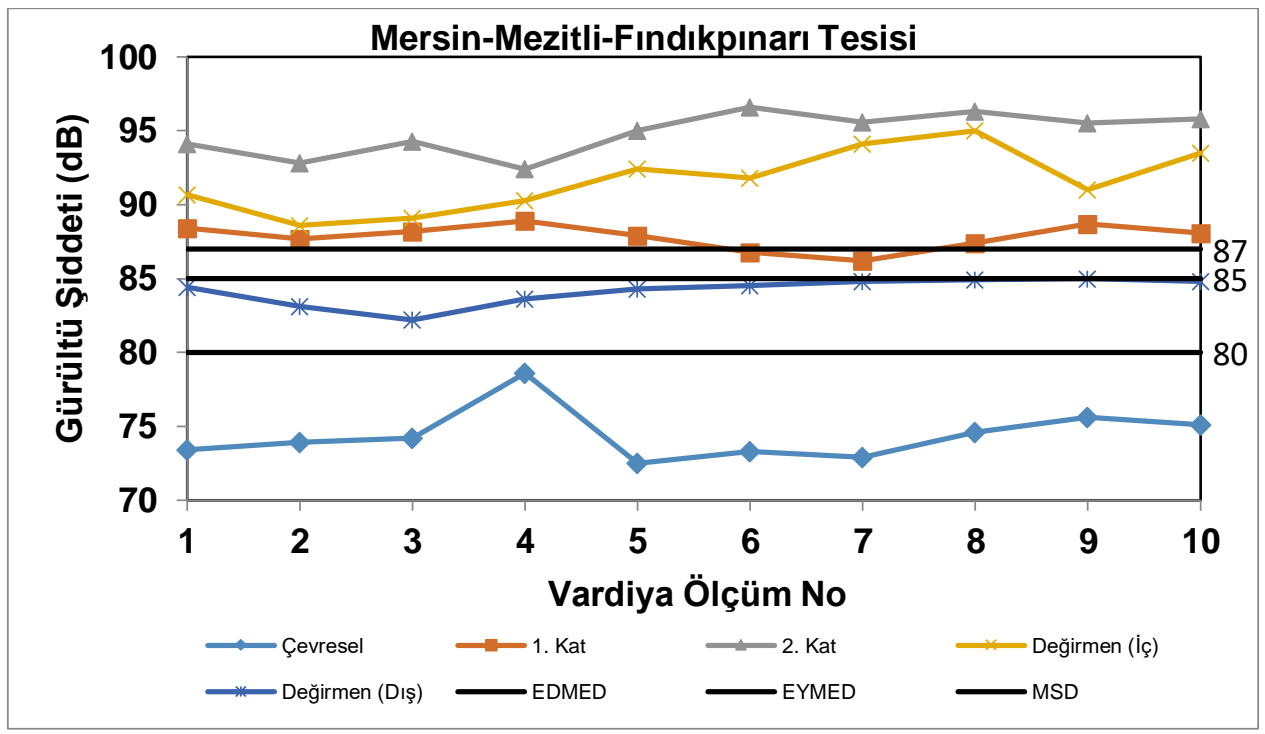

Şekil 8. Mersin-Mezitli-Fındıkpınarı krom zenginleştirme tesisinde gerçekleştirilen gürültü seviyesi ölçüm sonuçlarının yönetmelik en düşük ve en yüksek maruziyet eylem değerleri ile maruziyet sınır değerleri karşılaştırma grafiği.

Çalışma alanlarında, vardiya boyunca, yalnızca ölçümlerin gerçekleştiği prosesteki makineler ve masalardan kaynaklanan gürültü değil, nakliye araçları ve çeşitli bakım işlerinden kaynaklanan gürültü seviyeleri de dikkate alınmalıdır. Bu değerler, yalnızca işlemle sınırlı sürelerde gerçekleşmekle birlikte, çoğu zaman en yüksek maruziyet eylem değeri üzerinde olduğundan;

- Kişisel koruyuculardan, TS EN 352 (1 ya da 3) standardına sahip kulaklıkların, etkin ve sürekli kullanımının sağlanması,

- Bu koruyucuların kullanımları ile ilgili gerekli ve yeterli eğitimlerin sağlanması ve periyodik olarak tekrarlanmas1, 
- İş makinelerinin gürültüye sebep olan kısımlarında ses izolasyonu ile ilgili çalışmaların yap1lmas1,

- Değirmen ve masalarla, yan işlemlerde kullanılan konveyör, motor ve pompaların periyodik bakımlarının düzenli gerçekleştirilmesi, eskimiş ya da aşınmış parçaların, yenileriyle değiştirilmesi,

- Tesis içerisinde çalışanların dinlenme aralarının süre olarak artırılması ya da bu mümkün değilse bile mola sayısının artırılması,

- Etkin dinlenme ve gürültünün sağl1k üzerine etkilerinin azaltılabilmesi için, dinlenme aralarının; gürültüden arındırılmış, sessiz ortamlarda gerçekleştirilmesinin sağlanması,

- Çalışanların, düzenli odyometrik muayenelerinin gerçekleştirilmesi, gerekir.

Tesis içerisinde, daha detaylı ölçümlerin gerçekleştirilmesi ve yazılımların kullanılması ile çalışma alanlarının detay gürültü haritalarının oluşturulması, daha kesin ve hassas sonuçların elde edilmesini sağlayarak, gelecekte gürültüden kaynaklanabilecek olumsuzluklara karşı önlemlerin alınmasına ve risk analizlerinin hazırlanmasına yardımcı olacaktır.

\section{KAYNAKLAR}

Balcı, S. (2016). Çimento Üretiminde Toz ve Gürültü Maruziyetinin Değerlendirilmesi, İş Sağlığı ve Güvenliği Uzmanlık Tezi, T.C. Çalışma ve Sosyal Güvenlik Bakanlığı, İş Sağlığı ve Güvenliği Genel Müdürlüğü, Ankara.

Berger, E.H., Neitzel, R., ve Kladden, C.A. (2015). Noise Navigator Sound Level Database with Over 1700 Measurement Values, Univ. of Michigan, Dept. of Environmental Health Science, Ann Arbor, MI; Version 1.8, 3M Personal Safety Division EARCAL Laboratory, USA.

Canfeng, Z., Shujie, Y. ve Dong, L. (2012). Comprehensive Control of the Noise Occupational Hazard in Cement Plant, International Symposium on Safety Science and Engineering in China (ISSSE-2012) \& Procedia Engineering 43 ( 2012 ) 186-190. s.

Çalışanların Gürültü ile İlgili Risklerden Korunmalarına Dair Yönetmelik (2013). T.C. Aile, Çalışma ve Sosyal Hizmetler Bakanlığı, 28 Temmuz 2013 tarih ve 28721 sayılı Resmi Gazete (S:21). https://www.resmigazete.gov.tr/eskiler/2013/07/20130728-11.htm (Erişim: Aralık 2019).

Directive 2003/10/EC of the European Parliament and of the Council (2003). On the Minimum Health and Safety Requirements Regarding the Exposure of Workers to the Risks Arising From Physical Agents (Noise), Official Journal of the European Union, Brussels.

Ediz, İ.G., Beyhan, S., Akçakoca, H. Ve Sarı, E. (2002). Madencilikte Gürültüye Bağlı İşitme Kayıplarının İncelenmesi, Türkiye 13. Kömür Kongresi Bildiriler Kitabı,13-22. s., Zonguldak- Türkiye.

Energy Resources of Australia LTD. (ERA) (2014). Ranger 3 Deep Draft Environmental Impact Statement, Appendix 7, Noise and Vibration Impact Assessment, 13. s., Australia. 
Güler, Ç. ve Çobanoğlu, Z. (1994). Gürültü. T.C. Sağlık Bakanlığı, Temel Sağlık Hizmetleri Genel Müdürlüğü, Sağlık Projesi Genel Koordinatörlüğü, Çevre Sağlı̆̆ı Temel Kaynak Dizisi No:19, Ankara (ISBN 975-7572-44-6).

Güvercin, Ö. ve Aybek, A. (2003). Taş Kırma ve Eleme Tesislerinde Gürültü Sorunu, KSÜ Fen ve Mühendislik Dergisi 6 (2), 101-107. s., Kahramanmaraş (ISSN: 1301-2053).

Mining Industry Advisory Committee (MIAC), Department of Mines and Petroleum, Western Australia (2014). Guideline: Management of Noise in Western Australian Mining Operations, Australia (ISBN: 978-1-92-1163-92-0).

Mutlu, M., Sarı, M., Önder, M. ve Önder S. (2017). Bir Taşocağı ve Kırma-Eleme Tesisi’nde Gürültüye Bağlı İşitme Kayıplarının Bulanık Mantık Yöntemi ile Tahmin Edilebilirliği, Uluslararası Maden İşletmelerinde İşçi Sağlığı ve İş Güvenliği Sempozyumu'2017, 396-411 s., Adana (ISBN: 978-60501-1087-6).

Sekizinci Beş Yıllık Kalkınma Planı, DPT: 2626 - ÖİK: 637(2001). Madencilik Özel İhtisas Komisyonu Raporu, Metal Madenler Alt Komisyonu, Krom Çalışma Grubu Raporu, Ankara (ISBN 975-19-28621).

T.C. Aile, Çalışma ve Sosyal Hizmetler Bakanlığı, Türkiye'de İşyerlerinde İş Sağlığı ve Güvenliği Koşullarının İyileştirilmesi Projesi (İSGIP) (2015). Meslek Hastalıkları ve İş ile İlgili Hastalıklar Tanı Rehberi, http://www.isgum.gov.tr/rsm/file/isgdoc/isgip/isgip_saglik_tani_rehberi.pdf (Erişim: Mayıs 2020).

T.C. Aile, Çalışma ve Sosyal Hizmetler Bakanlığı, İş Sağlığı ve Güvenliği Genel Müdürlüğü (2018). Çalışanların Gürültü ile İlgili Risklerden Korunmalarına İlişkin Uygulama Rehberi, Ankara.

T.C. Sosyal Güvenlik Kurumu (2020). 2018 Yıllık İş Kazası ve Meslek Hastalığı İstatistikleri, http://www.sgk.gov.tr/wps/portal/sgk/tr/kurumsal/istatistik/sgk_istatistik_yilliklari (Erişim: Mayıs 2020).

TS EN ISO 9612, Türk Standardı, Akustik - Çalışma Ortamında Maruz Kalınan Gürültünün BelirlenmesiMühendislik Yöntemi (2009). Türk Standartları Enstitüsü, Ankara (ICS 13.140).

TS EN ISO 11204, Türk Standardı, Akustik - Makina ve Donanımdan Yayılan Gürültü - Bir İş İstasyonundaki ve Doğru Çevresel Düzeltmeler Uygulanmış Belirtilen Diğer Konumlardaki Emisyon Ses Basınç Seviyelerinin Tayini (2012). Türk Standartları Enstitüsü, Ankara (ICS 17.140.20). 